\title{
Income inequality and religion globally 1970-2050
}

\author{
JOSE NAVARRO and VEGARD SKIRBEKK
}

C conomic inequality is a paramount issue for the future of global affairs and interreligious rela-

Etions. This study contributes to the field by providing the first ever estimates of global inequality by religion. We combine estimations and projections of religious compositions and distribution of income by age and sex across the world between 1970 and 2050. Understanding economic inequality from a religious dimension can contribute to decreasing tension, creating targeted policies and reducing the risks of social upheaval and conflict.

We find that in societies with higher proportions of religiously unaffiliated populations, income distribution is more equal than in religious ones. We also describe the inequality of distribution of income within religious groups and find that Christian and Jewish societies tend to be the most unequal, while inequality has risen substantially across all societies, concomitant with strong economic growth. Societies formed of Muslim, Hindu and unaffiliated populations are among the more equal ones. Muslim societies have experienced the highest rise in income inequality of all religions since 1990.

When it is a question of money, everybody is of the same religion.

(Voltaire)

\section{Introduction}

Background

The $2015 \mathrm{PEW}-\mathrm{ACC}$ estimates of religious populations have opened a wide avenue for research on the religious development of world populations: ACC and PEW produced the first global dataset of affiliation by age and sex, covering 199 nations and more than 99 per cent of the global population, based on a large database of more than 2,500 surveys, registers and censuses (Skirbekk et al. 2010, 2015). We combine these with the UNU-WIDER income distribution survey data from the World Income Inequality Database (WIID) (UNU-WIDER 20I7) and the World Bank World Development Indicators data (WDI) (World Bank 201 7) to provide a global picture of the global income distribution by religion. 
Objective and value added

We aim to shed light on the economic weight of religious groups in the global economy and the distribution of income within them. This should be a helpful tool in further analysing the inconclusive relationship between religion and income inequality.

Methods

We combine religious distribution data from the World Religion Database and PEW-ACC with income distribution data from UNUWIDER and gross national income data from the World Bank WDI database. From this combined data we extrapolate distributions of income among the world's religious groups per country. We use also OECD projections and their methodology to produce global projections for economic growth and its distribution among religious groups until 2050.

Results

We show how income inequality has developed within and across religious groups since I 970. Consistent with the global observations of recent decades (Davies et al. 2015, Piketty 2015, Milanovic 2017), we observe an increase in economic inequality both across and within religious groups, but with marked differences between religions. Whereas Christians and Jews start at a high level of inequality and this rises only moderately, Muslims and the unaffiliated rise markedly, especially in the period between r 990 and 2or o. Buddhists are the only group experiencing a fall in inequality among its followers.

\section{Conclusions}

Christian and Jewish societies tend have the highest levels of economic inequality, while inequality has risen substantially across all societies, concomitant with strong economic growth since the r970s. Muslims, Hindus and the unaffiliated are among the more equal societies. Yet Muslim societies have experienced the greatest rise in inequality in the period between I 990 and 2010. Research to obtain more granularity on the relationship between inequality and religion is warranted. 


\section{Methods and data}

Religious affiliation data

PEW-ACC religious projections were the first ever global estimates of religion that took into account global religious demographic detail. They incorporated age-sex variation and took into account more than 2,500 demographic databases. The project was based on funding from Vegard Skirbekk's European Research Council grant (Grant Agreement 24I003-COHORT) and a Templeton funding grant provided to the PEW foundation. All projections were carried out by a model setup led by Marcin Stonawski who was deputy leader in Vegard Skirbekk's ACC (Age and Cohort Change group) and released as various $\mathrm{PEW}$ reports.

The 2015 PEW-ACC estimates of religious populations have opened a wide avenue for research on the religious development of world populations: ACC and PEW produced the first global dataset on affiliation by age and sex, covering I 99 nations and more than 99 per cent of the global population, based on a large database of more than 2,500 surveys, registers and censuses (Skirbekk et al. 2010, 201 5).

Data on religious affiliation was taken from a separate, unique project that estimated global religious affiliation by age and sex globally. Religious affiliation information from more than 2,500 data sources, including censuses, demographic surveys, general population surveys, and other studies were analysed - the largest project of its kind to date. ${ }^{1}$ These data were used to produce country-specific estimates on religious affiliation by five-year age groups separately for men and women. ${ }^{2}$ Census, survey, focus-group and other demographic data collection methods were used to identify belief

1 Details regarding the data sources, the procedures used in gathering the data, carrying out the estimations and harmonizing the data are presented in several technical reports and methodological articles (Stonawski et al. 2015).

2 Censuses were the primary source in 90 nations, which together cover $45 \%$ of all people in the world. Large-scale demographic surveys were the primary sources for 43 countries. General population surveys were the primary source of data for an additional 42 countries, representing $37 \%$ of the global population. Together, censuses or surveys provided estimates for I 75 countries representing $95 \%$ of the world's population. In the remaining 57 countries, representing $5 \%$ of the world's population, the primary sources for the religious-composition estimates include population registers and institutional membership statistics reported in the World Religion Database and other sources. 
systems as they relate to the demographic makeup of society, age and sex distribution, and geographic factors. Eighty-three per cent of the world's population had a religion in 2010 according to our estimates, and this proportion is projected to increase to 87 per cent by 2050 (Hackett et al. 2015). Our unique global collection of data on religious belief allows us to investigate variations in religious belief.

A limitation of our study is that our dependent variables are associated with countries, and countries are composed of numerous religious groups. As a simplifying approach, we analysed countries by majority religion, but ideally we would have all of our indicators broken out by religious group. Furthermore, our data have other biases in common with studies that use countries as units of analysis.

\section{Gross national income and inequality data}

The global estimation of gross national income and its distribution was made using an augmented Solow model (Barro and Sala-i-Martin 2004, Pinkovskiy and Sala-i-Martin 2009), combining the World Bank Development Indicators database with forecasts produced by the OECD and using the OECD methodology (OECD 20I7) to produce forecasts for the nonOECD member countries in our sample. ${ }^{3}$ We then combined these with

3 GDP growth projections used are from March 20 I 7. They are expressed in real per capita terms PPP, and are drawn following the methodology used in the Organization for Economic Cooperation and Development (OECD 2017). Where OECD projections are not available, we use our own growth projections which are based on an augmented Solow model of economic production, using a Cobb-Douglas function: where A represents productivity, $\mathrm{K}$ is capital, and $\mathrm{L}$ is labour. We assume that technology will evolve across countries as a process of catching up with the most developed economies, as has been the case in the period I 950-2010. Convergence depends on gross national income per capita, and the basic assumption is that as developing economies get closer to incomeper-capita levels of more developed economies, their productivity growth rate will slow down. By 2050, the end of our forecasting horizon, we assume the output gap will have closed and there will be no difference between PPP and real exchange rates. The rate at which they catch up depends on technology transfer and on the initial productivity gap with more developed economies.

The Bayesian modelling approach (Marin et al. 2005, Jones and Schneider 2005 ) allows for probability statements to be made directly about the unknown parameters, prior or expert opinion to be included in the analysis, and hier- 
the UNU-World Income Inequality Database data to produce a distribution of income for the different religious groups globally to 2050 .

Consistent with the methodology in our religious database (Stonawski et al. 2015), we use a macro-level approach, ignoring within-country variation in economic levels. In some countries, this clearly plays an important role, as economic variations between economic groups can differ greatly. However, many countries are completely dominated by one religion and within-country variation in income by religious groups is often smaller than variation between countries. We also correct for countries without a majority religion to keep this effect contained.

As the figure for income, we use gross national income (GNI) in purchase power parity (PPP) adjusted $20 \mathrm{II}$ constant International USD (World Bank 20I7).

GNI is a measure of income similar to the widely-used gross domestic product, but it adds to the GDP the rents earned by domestic residents of factor income (land, labour and capital) from abroad and subtracts rents and factor income of non-residents earned from the country.

The purchase power parity adjustment for income means that income figures between two countries are adjusted to show the price differences between the two countries. Prices vary considerably between industrialized and developing nations for both tradeable and non-tradeable goods; for example, an income of I, ooo USD per month in rural India affords a comfortable life for a family of four, while the same income in the US would barely cover the basic necessities of one person.

The use of constant dollars 20 I I USD means that the price level of 20 I I is kept as the reference for the duration of the time series, enabling us to compare the purchasing power of income across time, as well as countries.

archical descriptions of both local-scale and global features of the model. In this case we perform growth regressions with possible paths for all possible combinations of outcomes possible for the factors in our model (capital, labour and technology). Similar to the approach used by the UN Population fund in their estimations of world population, we produce a median forecast for income for each country that we estimate to be probable within a probability of $80 \%$. 


\section{Theory and background}

Religious affiliation is associated with economic growth (including differences in economic level and economic inequality) as well as demographic change (including differences in fertility). This paper aims to contribute to the literature on the socioeconomic determinants and consequences of religion and religiosity started by Max Weber (1905) and continued in contributions on religion and inequality including (Barro and McCleary 2003, McCleary and Barro 2006, Guiso et al. 2006, Glaeser and Sacerdote 2008, Becker and Woessmann 2010), who emphasize the relationship from religion to growth through the accumulation of human and physical capital.

Identifying, describing and understanding the effects of religious dimensions on economic development dimensions remains a challenge. Most research has been focused on smaller samples, usually from one region or nation, while there has been a lack of research focusing on global relationships.

As exposed in the excellent survey by Matthias Basedau, Simone Gobien and Sebastian Prediger (2017), some economic studies on religion have focused on income and its distribution. Several studies consider religion as the independent variable and consistently report a positive correlation with income inequality, suggesting that religion may cause inequality (Solt et al. $20 \mathrm{I}$, Solt 20I 4). However, the direction of causality could go the other way, where economic inequality leads more people to turn to religion.

Significant evidence suggests that people who are religious differ from their secular counterparts in their preferences concerning economic redistribution (Alesina and Giuliano 20 I I, Benabou and Tirole 2005, Guiso et al. 2003, Scheve and Stasavage 2006, Stegmueller 2013). Frequent churchgoers in Western democracies are less likely to support public spending which could reduce economic inequalities (Scheve and Stasavage 2006) or to vote for parties with redistribution on their agendas (Stegmüller 2013) than less frequent churchgoers. Political parties with conservative agendas are found to not prioritize redistribution (Hoffmann 2013 , Saroglou et al. 2004). One argument is that religiously-inspired ideas and values focus people's attention away from material and economic interests in favour of ideology, values and belief-based policies. Elaborating on this line of argument, Ana De $\mathrm{La} \mathrm{O}$ and Jonathan Rodden (2008) show, that in economically advanced democracies, poor religious people's preferences for morals appear to dominate over their preferences for redistribution, particularly in countries with large Catholic populations. 
There are also other mechanisms through which religious ideas may affect preferences and attitudes and, by extension, inequality. For example, religious individuals may derive psychological benefits from religion that reduce the perceived burden of health and economic insecurities and provide a sense of meaning, see also Dehejia et al. (2005), or may oppose welfare spending on the basis that it decouples work from reward (Benabou and Tirole 2005).

Moreover, religious organizations provide material resources to poor members (Hungerman 2005) that may substitute for social welfare spending and reduce the need for state-provided social insurance (Dehejia et al. 2005). Huber and Stanig (20I I) further propose that church-state financial separation and voter coalitions among rich and poor religious people counteract religious individuals' demand for welfare spending. Accordingly, rich and poor religious individuals form electoral coalitions in favour of lower taxation (and hence state redistribution), where the religious poor are compensated by the rich via charitable donations to the churches. These donations tend to benefit the religious poor - but to a lesser extent the secular poor (Huber and Stanig 20I I).

However, empirical evidence on the relationship between religious dimensions and redistribution preferences, voting behaviour, and attitudes towards the welfare state has so far been correlational, not causal, and has come almost exclusively from advanced economies.

As our figures show, religion and religiosity play a much bigger role in developing countries, where lower levels of societal development leave more room for religions to provide social and health services (Paldam and Gundlach 2013).

\section{Income distribution by religions}

Over the next two decades the structure of the world population as well as income levels are projected to undergo profound changes. Rapid demographic growth in Africa has been forecast to coincide with strong economic growth. Christians and Muslims will remain the largest religious groups, where Muslims will see a strong increase, while the religiously unaffiliated, Buddhists, and folk religionists are likely to experience a decline. See figure I which shows estimates and projections of religious affiliations from I970 to 2050 . 


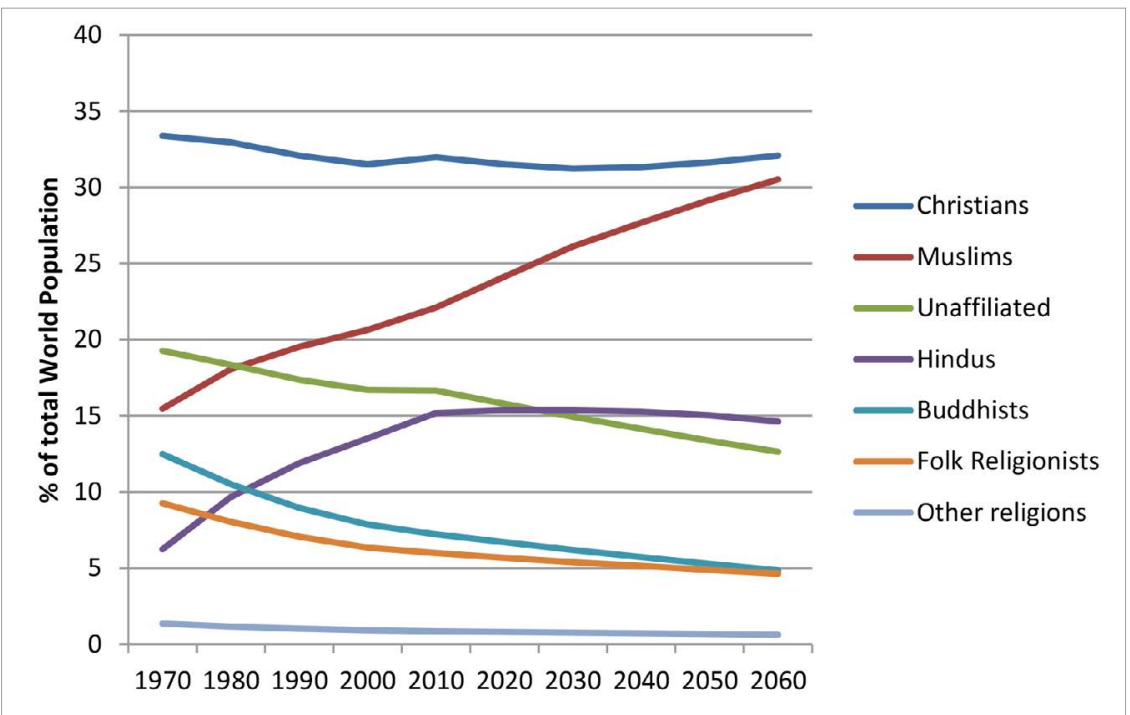

Figure 1. Global shares of religious groups from 1970 to 2010 and projections until 2050 (Johnson and Grim 2008; Stonawski et al. 2015).

As highlighted in Stonawski et al. (2015) and Johnson and Grim (2008), the stalling of population growth of the more secular East Asian and Western societies in the decades since 1970 has been followed by growth in more religious parts of South Asia and Africa. The religiously unaffiliated, which in 1970 made up close to 20 per cent of the global population, have been in decline ever since. China's stalling population growth, where an estimated 5 I per cent of the world's unaffiliated lived in 2010 , is the main reason for the decline in the size of this group. Hinduism will reach a plateau around 2025 , and will thereafter experience stagnation in terms of its world population share. The economic rise of countries with these religions dominant will be quite significant, especially in the context of the big emerging markets. Buddhists and folk religionists will continue their slow decline as a proportion of world affiliated following low fertility for the Buddhists and conversion to other religions in the case of folk religionists.

Figure 2 a shows the period between 1970 to 2010 , where we can observe growth that occurred within a forty-year period, where Hindus more than quadrupled in size and Muslims grew two and a half times. From 2010 to 2050 we see slower relative growth, see figure $2 \mathrm{~b}$, where the most important change is the Muslim population almost doubling from its 2010 level. From 

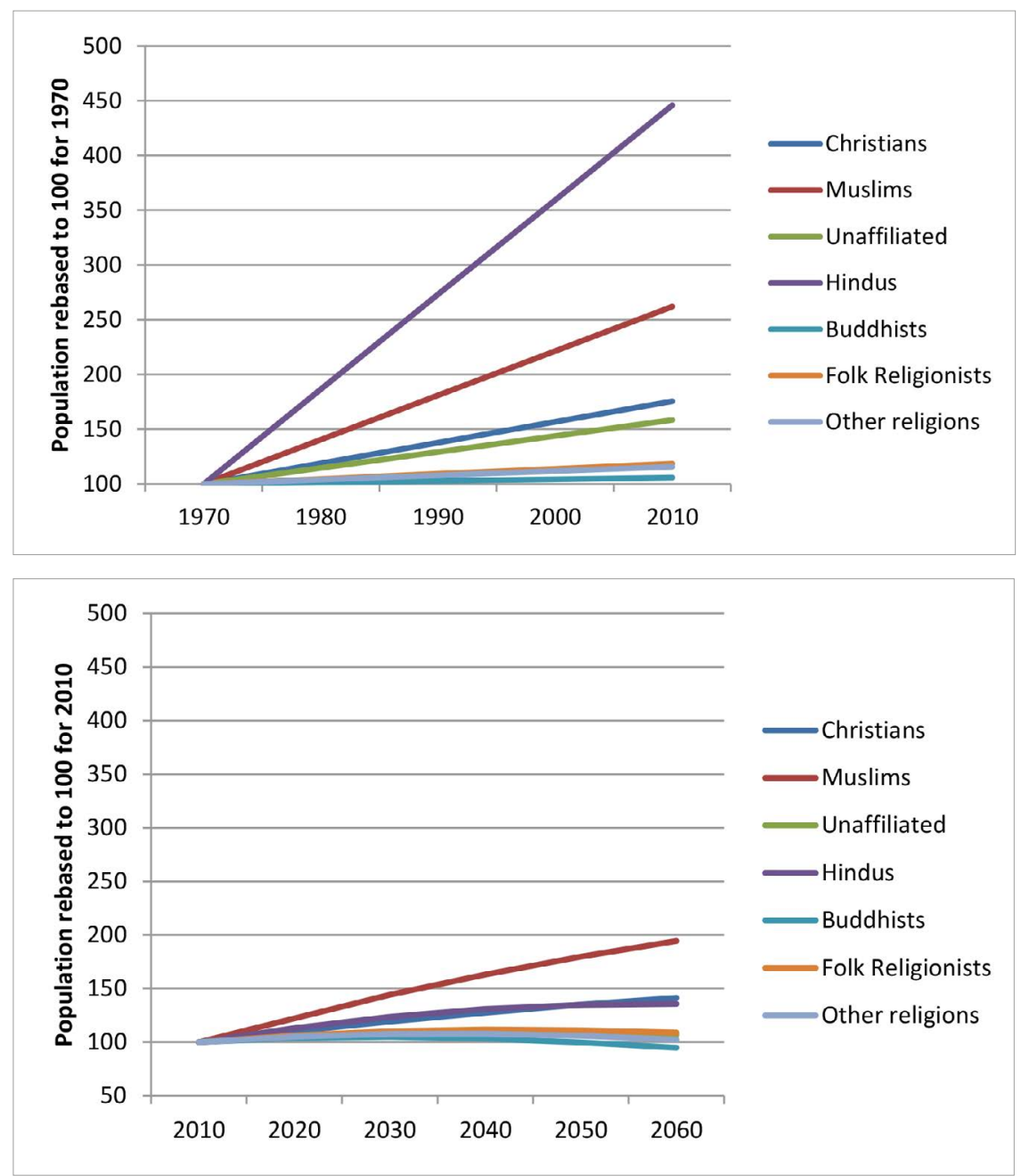

Figures 2a and b. Religious population growth 1970-2010 and 2010-2050 (Johnson and Grim 2008, Stonawski et al. 2015).

2010 onwards we are likely to observe a decline in numbers of Buddhists and the unaffiliated.

Having calculated the income distribution for all countries, we can now plot how inequality fares according to religion. From figure 3, consistent with the global rise in inequality, we find that all religious groups, except Buddhists, exhibit rises in the inequality of income distribution among their members. One has to take into account the lack of comparable survey data 


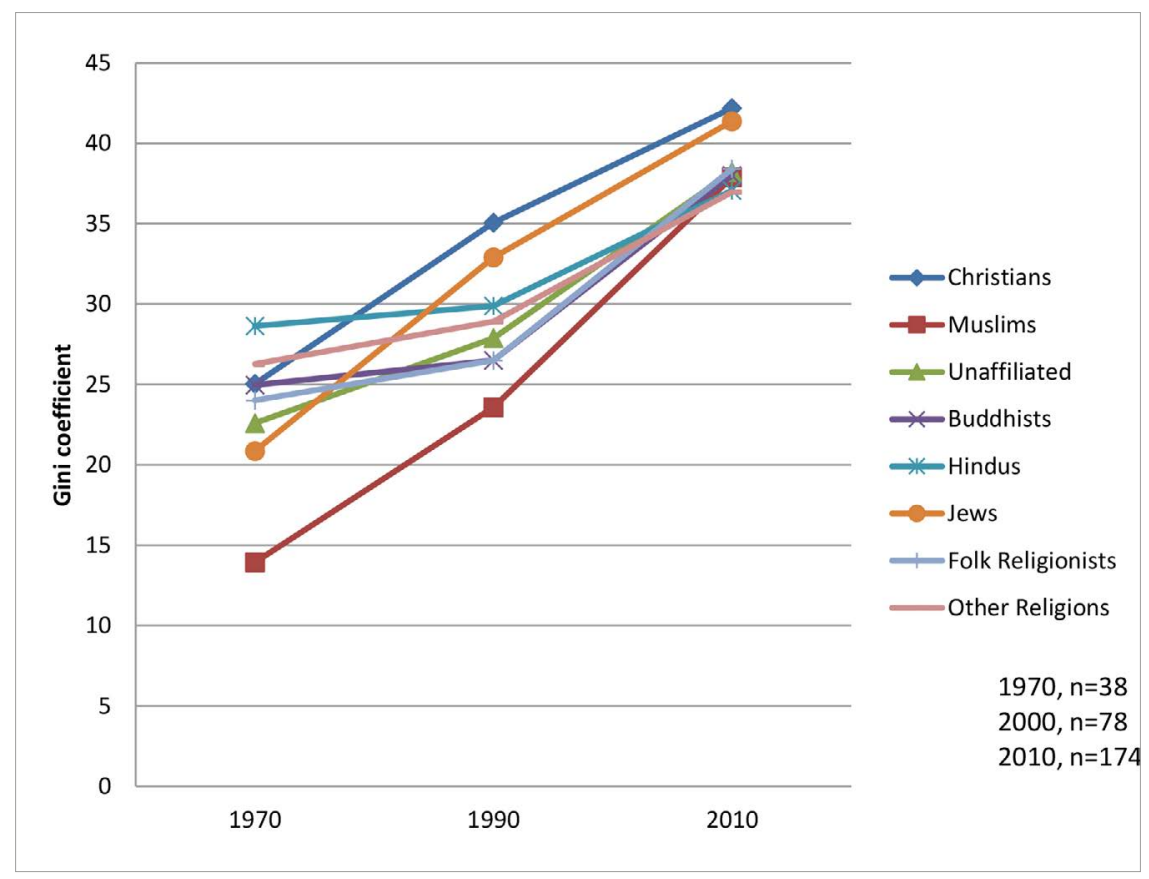

Figure 3. World religions' distribution of income by Gini coefficients (UNU-WIDER 2017, Stonawski et al. 2015, and our own calculations).

for the period before 1990 , the number of observations is restricted to 38 countries for the period between 1970 and I 980 . For I 990 to 2000 we have 78 observations and for 2000-2010 we have 174 .

The Gini coefficient is a widely-used measure of the dispersion of a distribution in the social sciences. It was created by Italian statistician Corrado Gini as a measure for the dispersion of income and wealth within a population (Gini I 92 I). It gives a numeric value to how far from a totally equal distribution of income the present distribution is. The higher the value, the more unequal the distribution is, and the more income or wealth is concentrated among fewer people. Here we have displayed the values as between o (total equality) and roo (total inequality). Values taken from the WIID database for the Gini index for OECD countries range between 24.5 for Slovenia and 50.4 for Chile. Scandinavian countries range between 27.4 for Denmark, 25.2 for Finland, 23.9 for Norway and 25.2 for Sweden, while Anglo-Saxon countries exhibit higher values, with 32.4 for the UK and 48 for the USA. African and Latin American countries are among the most unequal, with values of 60.8 for South Africa and 5 I.2 for Brazil. 


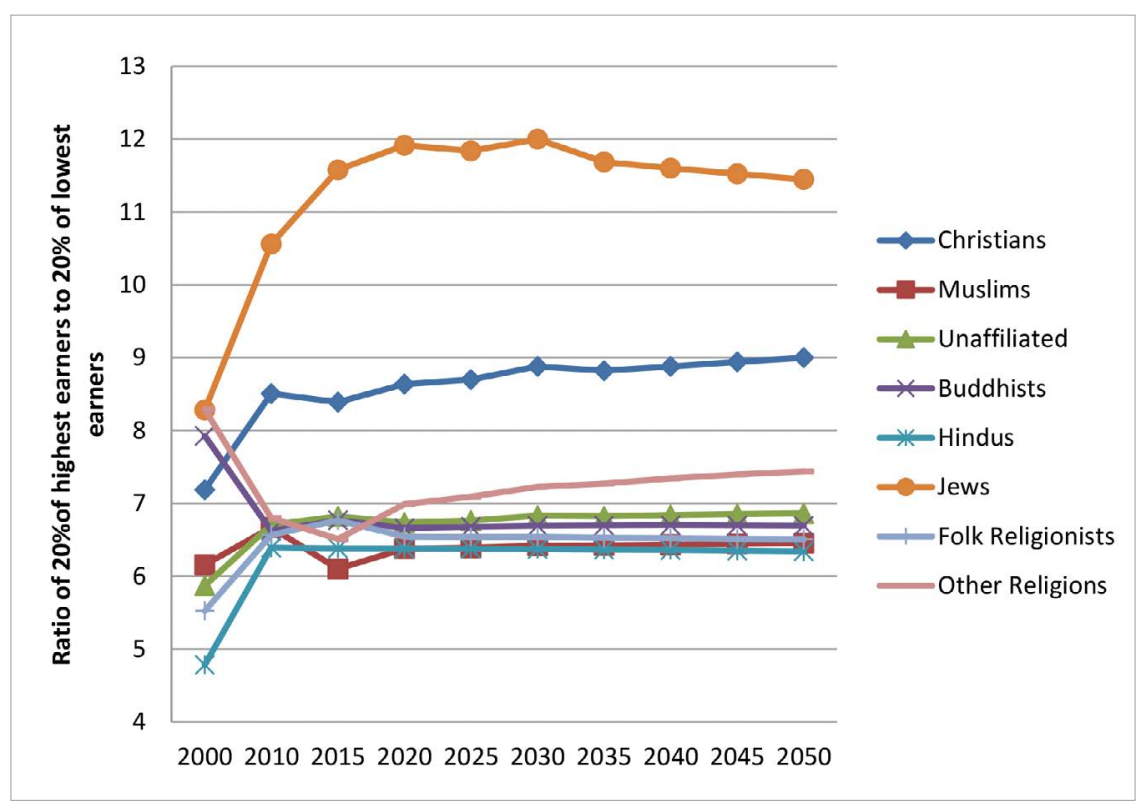

Figure 4. Economic inequality based on the 20/20 ratio (UNU-WIID 2017, Stonawski et al. 2015, and our own calculations).

We find that Jews and Christian populations have the greatest inequality regarding income among the faiths, with Gini-coefficients rising in this period from the low 20 in 1970 to more than 40 in 2010 for both religions. Hindus had the highest level of equality in 2010 at 37 . The unaffiliated groups also ranked highly in terms of equality of income distribution, at 38 , but have experienced a very pronounced rise in inequality, mainly due to China's increase in inequality from the late r $990 s$.

By regions, Christians in Europe are more equal, but Christian populations in Africa and the Americas contribute to a wider dispersion. Muslim societies in Asia Pacific exhibit distributions of income closer to their neighbouring societies, dampening the wider disparities of Muslim societies in the Middle East and Africa.

As per figure 4, we now plot the income distribution by religion by quintiles, or divided into five groups that account for 20 per cent of income receivers each. Here we plot the $20 / 20$ ratio, or the ratio of the top 20 per cent of earners to the 20 per cent least well off among the population (see Forbes 2000 for a list of measures of inequality and explanation of $20 / 20$ ratio). The $20 / 20$ ratio helps to give a more nuanced view of the distribution 
of income, especially when we have distributions with similar Gini coefficients (as is the case with Muslims, Hindus and Buddhists in our sample). It gives better information than the Gini on the crucial aspect of how redistribution of gross national income works (or does not) in a society between its richest and poorest members.

Consistent with the observation that income among Christians and Jews is more unequally distributed, we find both religions at the top of the scale. The top 20 per cent of Jewish income earners receive $\mathrm{I} 2$ times the income of the poorest 20 per cent whilst the figure is 8.7 for Christians respectively. We find declines in these ratios for Buddhists in the period from 1970 to 20I0.

If we look at the significant increase in inequality between 2000 and 2010 exhibited by Jews (increasing from 8.28 to 10.55) and Christians (from 7.I 8 to 8.5), we find that in both cases it is the increase in inequality of the US residents of both faiths that explains most of this increase. In this ro-year period, the income accruing to the top 20 per cent of earners increased from 46.9 to 5 I.I per cent. Of the 5.7 million Jews in the US, the wealthiest 20 per cent increased their average income from I60,000 USD to I 9 I,, 000 USD.

In our projections we assume inequality to remain constant from 2010 or the latest available survey date onwards.

All USD data are given in 20 I I constant prices, and at purchase power parity, or adjusted for differences in prices of common goods, to make the international comparison easier and more meaningful. Keeping the prices constant also enables us to compare income across the timespan of our study ( 1970 to 2050), taking account of inflation. In figures $5 \mathrm{a}$ and b we find the economic weight by religious group. In figure 5 a, in 2010 Christians agglomerate the highest proportion of global income at 40 trillion USD, more than the combined share of the unaffiliated (I 9 trillion USD), Muslims (I 4 trillion USD) or the Buddhists (6 trillion USD). In terms of growth, Hindus, Muslims and the unaffiliated have grown considerably since the I 970s, but it is remarkable that in 2010 both the unaffiliated and Muslims surpass the income of Christians in 1970, on the back of the fast pace of economic and population growth the world has experienced in this time frame. This has given rise to a shifting of economic weight away from the traditional centres of growth in the West and towards emerging markets. 

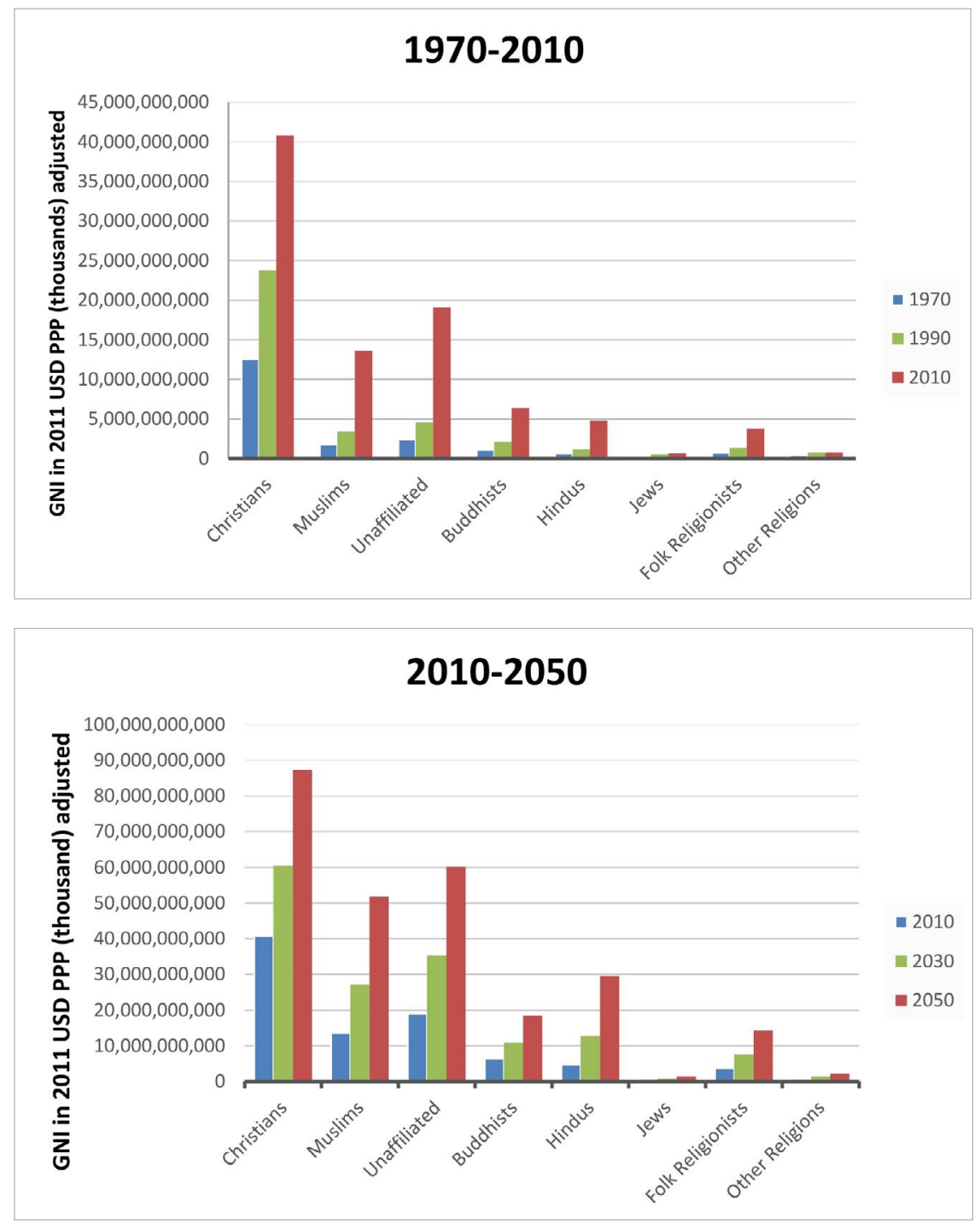

Figures $5 \mathrm{a}$ and $\mathrm{b}$. Income distribution by world religions; a tale of two periods (World Bank 2017, Stonawski et al. 2015, and our own calculations). 
Some religions weigh more in terms of contribution to global GDP. On the basis of the assumption that within-national variation in GDP by religion is equal ${ }^{4}$ the following global distribution of belief is given: see figure 5 a. Christians, although accounting for only 3r.4 per cent of the world's population, account for 49.3 per cent of global GDP. The unaffiliated were only I 6.4 per cent of the population, but represented 22.2 per cent of GDP. Muslims accounted for 23.2 per cent of the world population in 2010, but represented only I 2.3 per cent of global GDP. Hindus were i 5 per cent of the population, but their GDP was only 4.9 per cent.

If we now focus on figure $5 \mathrm{~b}$, we can see the probable paths of development for the economic weight of religious groups. The global estimation of gross national income using an augmented Solow model, combining the World Bank Development Indicators database with ACC-PEW forecasts for population growth and religious affiliation. We then combine these with UNU-World Income Inequality Database data to produce a distribution of income for the different religious groups globally to $2050 .{ }^{5}$

Based on this forecast methodology, we expect a growth in income of Christians to reach 87 trillion USD by 2050 . The unaffiliated would reach close to 60 trillion USD, Muslims 52 trillion USD and Hindus close to 30 trillion USD.

The relative income difference between Christians and all other religious groups will most probably continue to converge, as it did in the period 1 970-2010. Our projections show that by 2050 both Muslims and the unaffiliated could well be surpassing the income levels of Christians in 20 Io by some margin. In the period we forecast, 2010-2050, Hindus will experience the highest growth in income, and will surpass in 2050 the level of income

4 Clearly, GDP-group variation within countries may differ between religions, yet since many countries are dominated by one religion (Stonawski et al. 2015), these changes are often relatively modest.

5 GDP growth projections used are from March 20 I 7. They are expressed in real per capita terms PPP, and are drawn following the methodology used in the Organization for Economic Cooperation and Development (OECD) report 'Looking to 2060' (OECD 2017). Consistent with the methodology used in this study, we use a macro-level approach ignoring within-country variations in economic levels. In some countries this clearly plays an important role, as economic variations between economic groups can be great. However, many countries are completely dominated by one religion and within-country variations in income by religious groups are often smaller than variations between countries. We also correct for countries without a majority religion to keep this effect contained. 


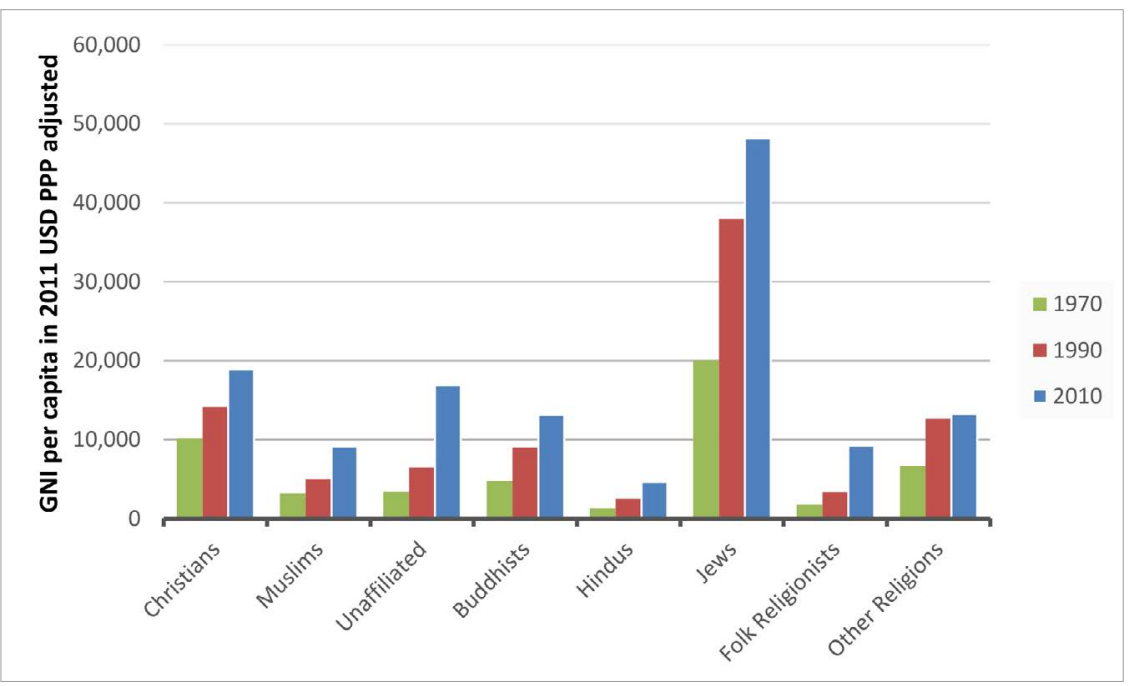

Figure 6. Income per capita by religion 1970-2010 (World Bank 2017, Stonawski et al. 2015, and our own calculations).

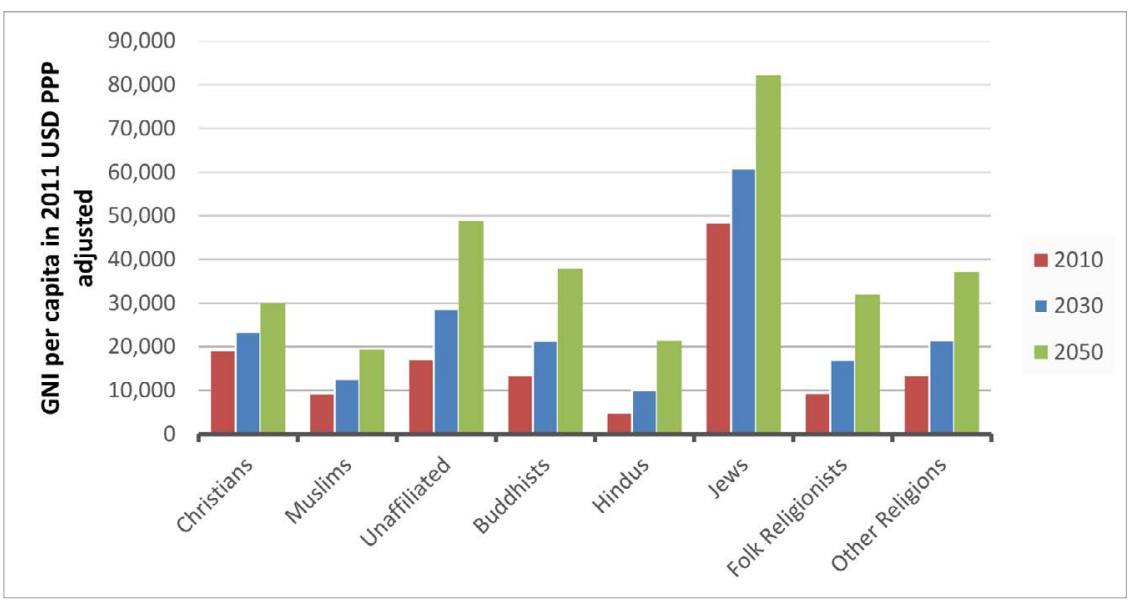

Figure 7. World distribution of income per capita by religion 2010-50 (World Bank 2017, Stonawski et al. 2015, and our own calculations).

of Christians in 1990. As remarkable as that growth may seem, it actually represents a lower rate of convergence between richer and poorer than that experienced in the period between 1970 and 2010 , as population growth decelerates globally.

As per figures 6 and 7, we can see the evolution of income per capita in these two periods. In per capita terms, we can observe how the average 
income has evolved in this time frame for the different religious groups. Christians and Jews dominated in the I970s, and we have seen a process of catch-up by all religious groups, and even more by the unaffiliated, who on the back of China's remarkable economic performance, rise five-fold to almost close the gap on Christians.

If we now take the mid-point projections for our forecasts for growth to 2050 , we find that the unaffiliated and Hindus are projected to make the greatest improvements, propelled by different factors. Whereas Hindus enjoy the demographic benefit that a rising working-age population provides, the unaffiliated are propelled by China's transition to a consumer society, which according to OECD forecasts will in 2050 have the average per capita income of the average Eurozone member in 2015 of close to 35,000 USD. Of note are also the projected growth rates of Muslim societies, which by 2050 will have on average the per capita income of Christian societies in 2010 of close to 18,000 USD.

\section{Beyond the averages, the inequality aspects of religions}

So far we have been describing the average income of religious groups. In this section we disaggregate and look at the relative income of the population, broken down into 20 per cent income brackets (quintiles).

In figure 8 we show the world income for the top quintile. Supposing we have constant inequality distribution in the time frame between 2010 to 2050 , we find that the top $20 \%$ of income earners are dominated by Christians, with all groups experiencing high growth, especially the wealthier Hindus. At 40 trillion USD, the share of income of the wealthiest 20 per cent of Christians in 2050 will be as big as that for the overall population in 20ro, in the case of Hindus, which are projected to grow much faster, that share would be four times higher at $\mathrm{I} 3.5$ trillion USD.

In figure 9 we study the middle classes. The 'middle classes' are defined as the 60 per cent of the population comprised between the top 8oth percentile and the lowest 20 th percentile. Their combined income is around the same as the top 20 per cent for most religious groups. Only in the case of the unaffiliated does it represent a bigger share.

As per figure Io, the lowest 20 per cent of income earners represent less than a 2oth of the overall economic weight, with wide variations among religions. This is where the comparison with the $20 / 20$ ratio can be seen in detail. Whereas the least well-off Christians earn nine times less than the 


\section{World Income by religion by Quintiles $2010 / 50$, the top $20 \%$}

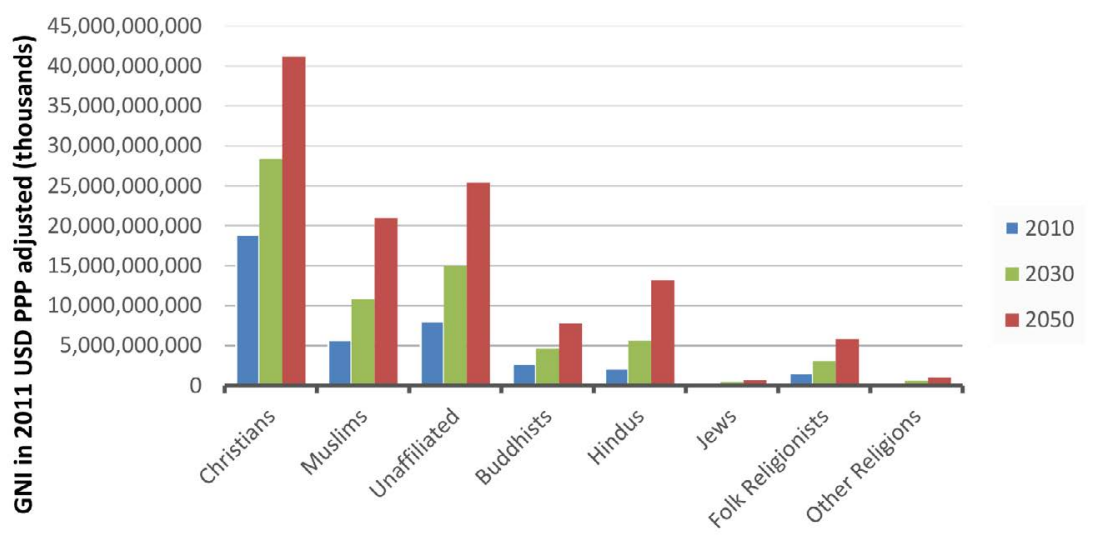

Figure 8. World income by religion by quintiles, 2010-2050; the top 20 per cent (World Bank 2017, UNU-WIDER 2017, Stonawski et al. 2015, and our own calculations).

\section{World Income by religion by Quintiles $2010 / 50$, the middle classes (20\%-80\% of population)}

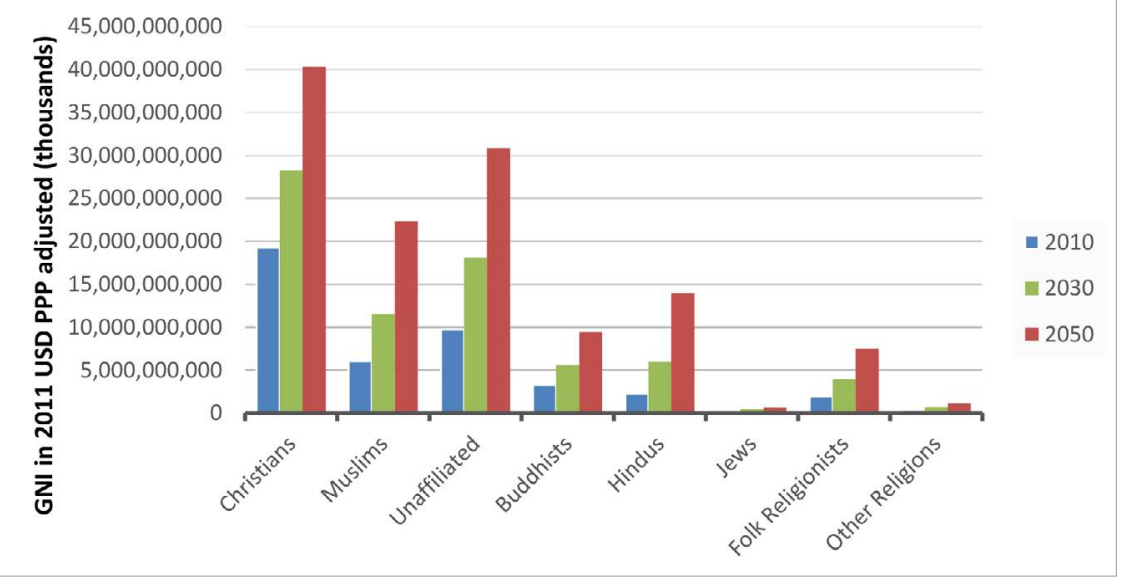

Figure 9. World income by religion; the middle classes (World Bank 2017, UNU-WIDER 2017, Stonawski et al. 2015, and our own calculations). 


\section{World Income by religion by Quintiles 2010-50, the poor (low 20\%)}

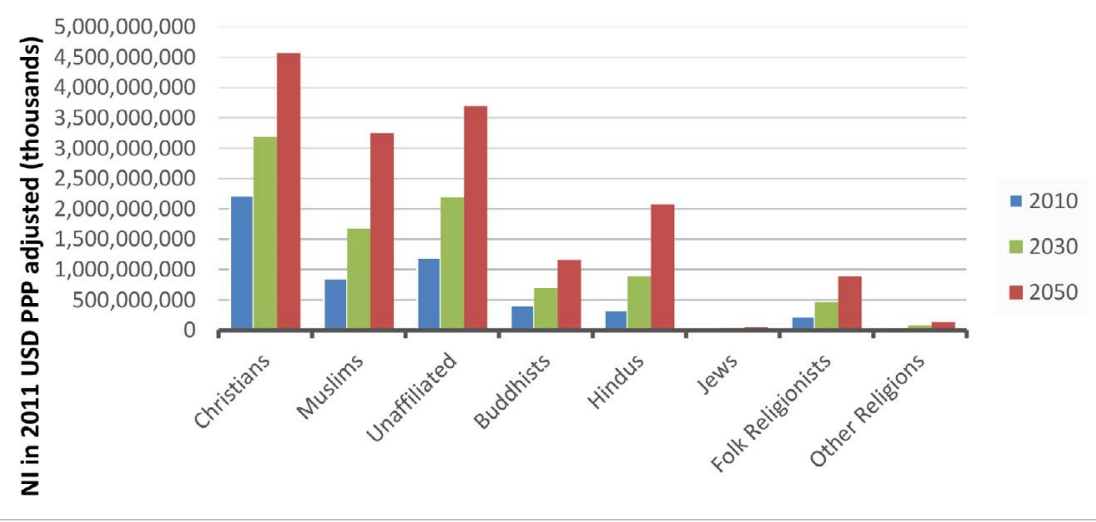

Figure 10. World income by religion; the lowest 20 per cent of income earners (World Bank 2017, UNU-WIDER 2017, Stonawski et al. 2015, and our own calculations).

wealthiest 20 per cent, Muslim and Hindus have closer gaps between rich and poor.

In figure I I we can see the average income per capita for each of the religions, and then the income of each 20 per cent section (quintile) of the population. For example, for Christians within the first quintile (ChristiansQ $I$, i.e. the lowest $20 \%$ of income earners), the average income in 2010 is 5 , I 24 USD. ChristiansQ 5 represents the fifth quintile (the highest earning 20\%) - the average income of 43,595; ChristiansQ2-4 represents the average income of the middle three quintiles (between 20 and $80 \%$ of income earners), with an average income per capita of I $4,859_{5}$ USD.

Here we only present the data, and leave it for future research projects to look into the very interesting questions raised by displaying how the lowest 20 per cent of income receivers fare within the respective religions. The fact that the unaffiliated lowest quintile earns more than the equivalent Christians (5,325 USD to 5, I 24 USD respectively) while the highest quintile of Christians earns 43,595 USD compared to the unaffiliated's 35,706 USD. This points to stark differences in redistributive policies that have been remarked on in the literature (Solt et al. 20 I I, Solt 20 I 4), and that our data may provide global proof of. 


\section{PER CAPITA INCOME BY RELIGIONS AND QUINTILES}

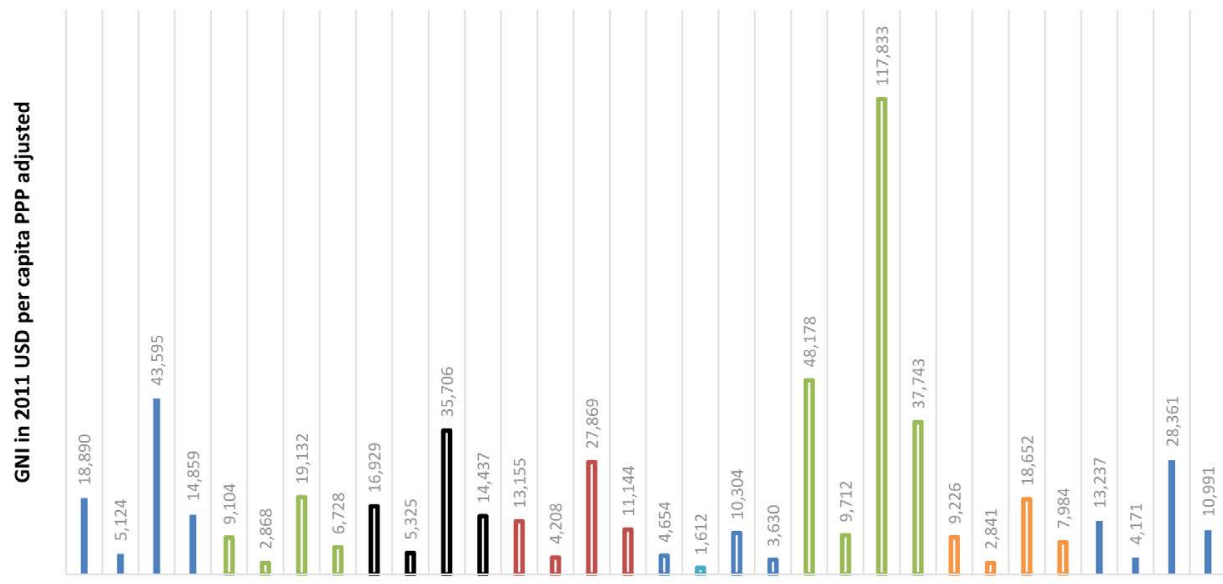

Figure 11. Income distribution per capita by quintiles and religions in 2010 (World Bank 2017, UNUWIDER 2017, Stonawski et al. 2015, and our own calculations).

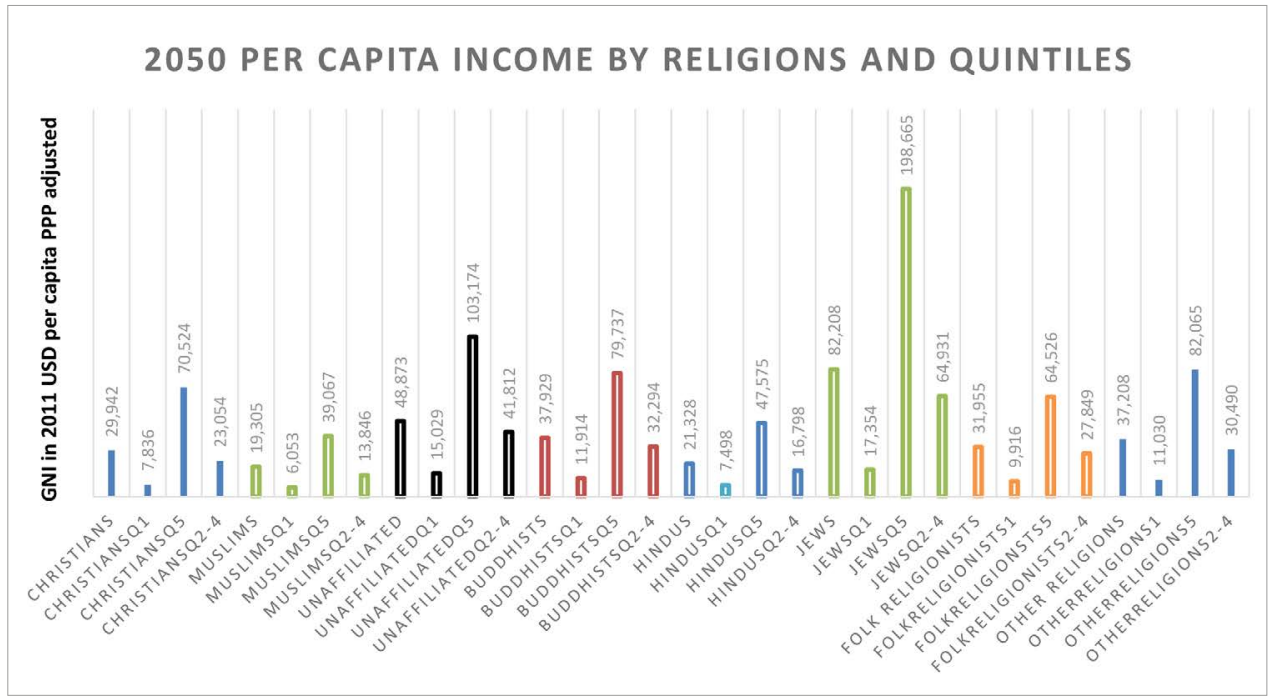

Figure 12. Income distribution per capita by quintiles and religions in 2050 (World Bank 2017, UNUWIDER 2017, Stonawski et al. 2015, and our own calculations) 


\section{The sources of economic growth, a brief look at emerging markets}

The growth in income described above has been especially remarkable in emerging markets; here we take a brief look at the developments in the two periods we focus on.

As per figure $\mathrm{I}_{3}$, if we look in detail at the seven populous emerging market economies (Brazil, Russia, India, China, Nigeria, Indonesia and South Africa), we find between 1970-2010 the startling growth that has increased the economic prominence of the unaffiliated, Hindus and Muslims.

The increase in income in this period was of a factor of seven for both Christians and the unaffiliated and of more than ten for Hindus, Buddhists and Muslims.

These big seven economies contributed close to 50 per cent of all growth in the period between 1970 and 2010 . As per figure 14 , our projections forecast that the contribution of this group may well exceed that proportion to around 66 per cent of overall growth.

\section{Conclusion}

To conclude, this study has shown results of our estimations and projections of religious compositions by age and sex for populations across the world. The ACC-PEW project was the first to attempt to provide harmonized and reliable estimates concerning religious groups globally by demographic detail. Availability of this kind of data is crucial for improving the quality of future scientific work.

In terms of the economic weight and the inequality of distribution of income, we find that Christians are, and will remain by 2050, the most economically influential group, with a total GNI at PPP of over 87 trillion 20I I USD. The unaffiliated will remain as the second largest group. Despite unaffiliated numbers globally stagnating, they will still grow in economic influence. Demographic dividends propel Hindus, Muslims and Christians in that order.

In the BRIC-NIS context, the unaffiliated and Hindus will rise to become the two most important economic groups. Especially remarkable is the rise of the Hindus since 1970.

We find that in societies with greater shares of religiously unaffiliated populations, income distribution is more equal than religious ones. We adjust for income levels, but this may be due to the 'Kuznets effect', whereby 


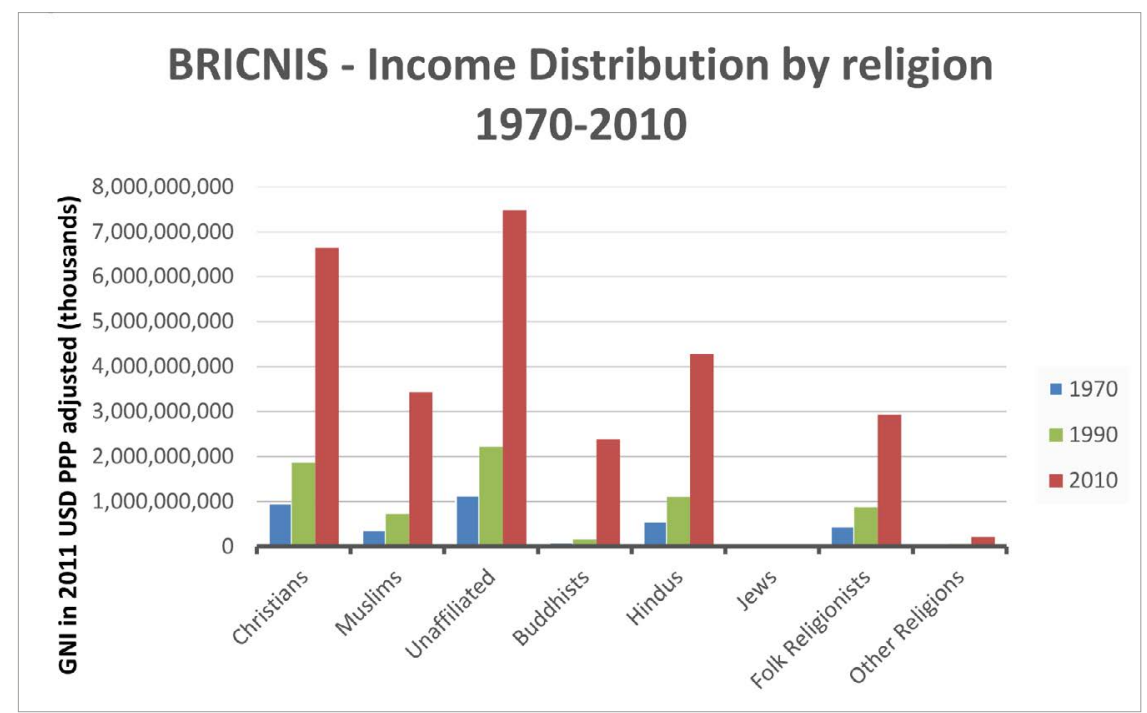

Figure 13. The sources of economic growth; the view from emerging markets 1970-2010 (World Bank 2017, UNU-WIDER 2017, Stonawski et al. 2015, and our own calculations).

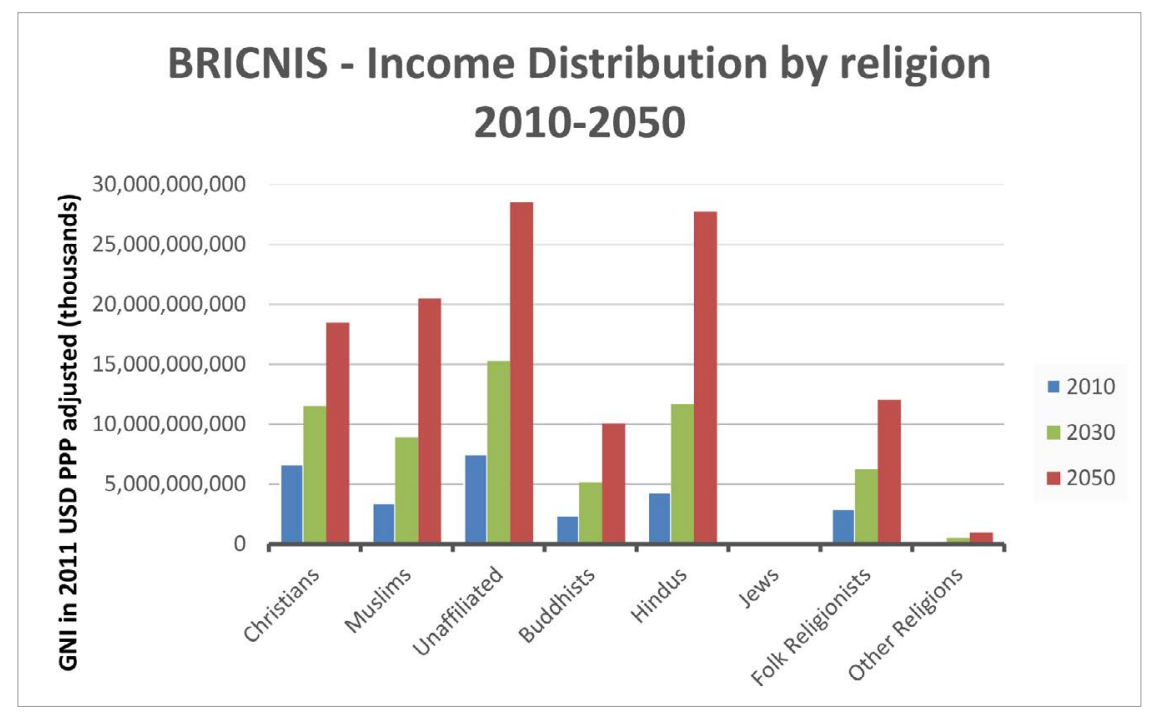

Figure 14. The future of economic growth; the view from emerging markets 2010-2050 (World Bank 2017, UNU-WIID 2017, Stonawski et al. 2015, and our own calculations). 
societies in the early stages of development experience periods of high inequality in a capital accumulation phase. China is the big outlier in terms of this observation. We assume constant inequality from 2010 , and inequality has risen sharply within China since 1970. Its transition to a more developed society would actually reinforce the observation in the coming decades.

In terms of religions, Christian and Jewish societies tend to be the most unequal, while inequality has risen substantially across all societies, concomitant with strong economic growth. Muslims, Hindus and the unaffiliated are among the more equal societies. Muslim societies have experienced the highest rise in income inequality of all religions since 1990.

Economic inequality is a paramount issue in the future of global affairs and interreligious relations. This study contributes by providing the first ever estimates on global inequality by religion. Understanding religious inequality can contribute to decreasing tension, creating targeted policies and reducing the risks of social upheaval and conflict.

Jose Navarro is a researcher at Columbia University. His research interests are many and varied, in recent times focusing on the interaction of economic inequality and culture and cultural institutions, especially from the macroeconomic angle. He has published on inequality and economic growth, as well as banking and finance.

Vegard Skirbekk is Clinical Professor of Population and Family Health at Columbia University, New York and Senior Researcher at the Norwegian Institute of Public Health, Oslo. His key professional interest lies in understanding the implications of demographic changes globally, especially how well nations undergo the demographic transition in terms of sustainability, culture and economic productivity. He has published extensively on fertility and health; ageing, health and productivity; culture and demographic change; age and cohort change; as well as demographic change and future development.

\section{Reference}

Alesina, Alberto, and Paola Giuliano, 20 r r. 'Preferences for redistribution' in Handbook of Social Economics (Amsterdam, Elsevier), pp. 93-I 3 I

Atkinson, A. B., I 975. The Economics of Inequality (Oxford, Clarendon Press)

Barro, Robert J., and Rachel McCleary, 2003. 'Religion and economic growth across countries', American Sociological Review, 68(5), p. 760

Barro, Robert J., and Xavier Sala-i-Martin, 2004. Economic Growth (Cambridge MA, MIT Press)

Basedau, Matthias, Simone Gobien, and Sebastian Prediger, 20I 7. 'The ambivalent role of religion for sustainable development: a review of the empirical 
evidence', SSRN Electronic Journal, 297, <https://doi.org/I0.2 I 39/ ssrn.2976I $74>$

Becker, Sascha O., and Ludger Woessmann, 2010. 'The effect of Protestantism on education before the industrialization: evidence from i 8 I 6 Prussia', Economics Letters, Io7(2), pp. 224-8

Benabou, Ronald, and Jean Tirole, 2005. Belief in a Just World and Redistributive Politics <https://doi.org/I0.3386/w I I 208 >

Borooah, Vani, and Sriya Iyer, 2004. 'Religion and fertility in India: the role of son preference and daughter aversion', <https://doi.org/Io.I7863/CAM.54Io>

Davie, Grace, 2007. 'Vicarious religion: a methodological challenge' in Everyday Religion, ed. Nancy T. Ammerman (Oxford University Press), pp. 2 I-36

Davies, J. B., R. Lluberas, and A. F. Shorrocks, 20I 7. 'Estimating the level and distribution of global wealth, 2000-2014', Review of Income and Wealth, 63, pp. 73 I-59, <https://doi: Io. I I I / roiw.I 23 I 8 >

Dehejia, Rajeev, Thomas DeLeire, and Erzon F. P. Luttmer, 2005. Insuring Consumption and Happiness through Religious Organizations, NBER Working Paper, I I 576, <https://doi.org/I0.3386/wi I 576>

De La O, Ana L., and Jonathan A. Rodden, 2008. 'Does religion distract the poor?' Comparative Political Studies, 4 I (4-5), pp. 437-76

Forbes, Kristin J., 2000. 'A reassessment of the relationship between inequality and growth', The American Economic Review, 9o(4), pp. 869-87

Gini, Corrado, I92 I. 'Measurement of inequality of incomes', The Economic Journal of Nepal, 3 I ( I 2 I), p. I 24

Glaeser, Edward L., and Bruce I. Sacerdote, 2008. 'Education and religion', Journal of Human Capital, 2(2), pp. I 88-2 I 5

Guiso, Luigi, Paola Sapienza, and Luigi Zingales, 2003. 'People's opium? Religion and economic attitudes', Journal of Monetary Economics, 50(I), pp. 225-82

-2006. 'Does culture affect economic outcomes?' The Journal of Economic

Perspectives: A Journal of the American Economic Association, 2o(2), pp. 23-48

Hackett, Conrad, Marcin Stonawski, Michaela Potančoková, Brian J. Grim, and Vegard Skirbekk, 2015. 'The future size of religiously affiliated and unaffiliated populations', Demographic Research, 32, pp. 829-42

Hoffmann, Robert, 2013. 'The experimental economics of religion', Journal of Economic Surveys, $27(5)$, pp. 8 I 3-45, <doi: Io. I I I I/j.I 467-64 I 9.20 I I.007 I 6.x>

Huber, John D., and Piero Stanig, 20 I I. 'Church-state separation and redistribution', Journal of Public Economics, 95 (7), pp. 828-36, <https://EconPapers. repec.org/RePEc:eee:pubeco:v:95:y:20 I I :i:7:p:82 8-836>

Hungerman, Daniel M., 2005. 'Are church and state substitutes? Evidence from the 1996 welfare reform', Journal of Public Economics, 89( I I-I 2), pp. 2245-67

Johnson, Todd M., and Brian J. Grim (eds.), 2008. World Religion Database: 
International Religious Demographic Statistics and Sources (Leiden and Boston, Brill)

Jones, Garett, and W. Joel Schneider, 2005. 'Intelligence, human capital, and economic growth: a Bayesian Averaging of Classical Estimates (BACE) approach'. SSRN Electronic Journal, I I (I), pp. 7 I -93 , <https://doi. org/I0.2 I39/ssrn.55248 I >

Marin, Jean-Michel, Kerrie L. Mengersen, and Christian Robert, 2005. 'Bayesian modelling and inference on mixtures of distributions' in Handbook of Statistics, vol. 25 (Amsterdam, Elsevier), pp. 459-507

McCleary, Rachel M., and Robert J. Barro, 2006. 'Religion and economy', The Journal of Economic Perspectives: A Journal of the American Economic Association, 2o(2), pp. 49-72

Milanovic, Branko, 2006. Worlds Apart: Measuring International and Global Inequality (Princeton University Press)

-2017. 'Towards an explanation of inequality in premodern societies: the role of colonies, urbanization, and high population density', The Economic History Review, pp. I-I 9

OECD, 2or 7. 'GDP long-term forecast', OECD iLibrary, <http://dx.doi. org/ı. I $787 / 4537 \mathrm{dc} 58$-en>

Paldam, Martin, and Ella Gundlach, 20 I 2. 'The religious transition: a long-run perspective', Public Choice, I 56(I-2), pp. 105-23

Piketty, Thomas, 2014. Capital in the Twenty-First Century (Cambridge MA, Harvard University Press)

-201 5. 'About capital in the twenty-first century', The American Economic Review, I05(5), pp. 48-53

Pinkovskiy, Maxim, and Xavier Sala-i-Martin, 2009. Parametric Estimations of the World Distribution of Income, NBER Working Paper, I 5433, <https://doi. org/I0.3386/wi 5433>

Saroglou, Vassilis, Vanessa Delpierre, and Rebecca Dernelle, 2004. 'Values and religiosity: a meta-analysis of studies using Schwartz's model', Personality and Individual Differences, 37(4), pp. $72 \mathrm{I}-34$

Scheve, Kenneth, and David Stasavage, 2006. 'Religion and rreferences for social insurance', Quarterly Journal of Political Science, I (3), pp. 255-86

Skirbekk, Vegard, Eric P. Kaufmann, and Anne Goujon, 20 Iо. 'Secularism, fundamentalism, or Catholicism? The religious composition of the United States to 2043', Journal for the Scientific Study of Religion, 49(2), pp. 293-3 Io

Skirbekk, Vegard, Michaela Potančoková, Conrad Hackett, and Marcin Stonawski, 2015. 'Religious affiliation among older age groups worldwide: estimates for 2010 and projections until 2050', The Journals of Gerontology: Series B: gbw I44, <https://doi.org/Io. I093/geronb/gbw I 44>

Solt, Frederick, 20 I 4. 'Reversing the Arrow? Economic inequality's effect on religiosity' in Religion and Inequality in America: Research and Theory on Religion's 
Role in Stratification, eds. L. Keister and D. Sherkat (Cambridge University Press), pp. 337-54

Solt, Frederick, Philip Habel, and J. Tobin Grant, 20 I r. 'Economic inequality, relative power, and religiosity', Social Science Quarterly, 92(2), pp. 447-65

Stegmueller, Daniel, 20 1 3. 'Religion and redistributive voting in Western Europe', The Journal of Politics, 75 (4), pp. 1064-76

Stiglitz, Joseph E., 20 I 2. The Price of Inequality: How Today's Divided Society Endangers Our Future (New York, W. W. Norton \& Company)

Stonawski, Marcin, Brian Grim, Vegard Skirbekk, Philip Connor, Michaela Potančoková, and Conrad Hackett, 2015 . 'Global population projections by religion: 2010-2050', Yearbook of International Religious Demography 2015, pp. 99-I I 6

UNU-WIDER, 20 17. WIID - World Income Inequality Database (WIID 3.4 ), United Nations University UNU-WIDER, <https:/www.wider.unu.edu/ project/wiid-world-income-inequality-database> (accessed January 2017)

Weber, Max, I 905. The Protestant Ethic and the "Spirit" of Capitalism and Other Writings (New York, Penguin Books, 2002)

World Bank, 2or 7. World Development Indicators (WDI) database, The World Bank, <https://data.worldbank.org/data-catalog/world-development-indicators $>$ (accessed April 2017) 